\title{
Proximate, mineral and fatty acid compositions of healthy recipes used in Fit, Eat, Active, Training (F.E.A.T) programme
}

\author{
Nurulhusna Abdullah', Hasnah Haron ${ }^{2}$, Ruzita Abd Talib ${ }^{1}$, Wan Nurul Najwa \\ Wan Nik $^{1}$ \& Wirdah Mohamed ${ }^{1}$
}

${ }^{1}$ Nutritional Sciences Programme \& Centre for Community Health Studies (ReaCH), Faculty of Health Sciences, Universiti Kebangsaan Malaysia, Kuala Lumpur, Malaysia; ${ }^{2}$ Nutritional Science Program \& Centre for Healthy Aging and Wellness, Faculty of Health Sciences, Universiti Kebangsaan Malaysia, Kuala Lumpur, Malaysia

\begin{abstract}
Introduction: Many people are seeking knowledge and skills about preparing healthy meals at home. This study aimed to determine the content of nutrients in 60 healthy dishes prepared for the recipe book Mudah, Sihat, Sedap used in the F.E.A.T nutrition intervention programme. The recipe book was developed as an educational material to guide participants in preparing healthy meals at home. Methods: A needs assessment survey was done to identify food preferences for breakfast, lunch and dinner of obese and overweight respondents. Recipes for these foods were then modified to reduce the calorie, fat, and sugar contents, while adding in fibre sources. Proximate analysis was done based on standard methods of AOAC, while total carbohydrate and calorie contents were calculated using the differentiation and Atwater methods, respectively. Mineral content was determined using atomic absorption spectrophotometer, while fatty acids content was analysed by gas chromatography using the FAME method. Results: Proximate analysis results showed that Kobis Goreng had the most calories (305 kcal/100g) $(p<0.05)$ in all categories. Mineral analysis showed that sodium was significantly highest $(p<0.05)$ in Asam Pedas Daging (554 mg/100g). For fatty acid analysis, Masak Lemak Telur Itik had the highest amount of MUFA (45.1\%), Masak Lemak Sotong had the highest amount for SFA (71.8\%), and Masak Lemak Cili Api Udang had the highest amount of PUFA (33.7\%). Conclusion: This study successfully modified original recipes of selected cuisines used in the recipe book, which contained lower calories compared to original recipes. The calorie and nutrient values for each recipe will be included as nutrition composition information in the recipe book.
\end{abstract}

Keywords: obesity, calories, proximate contents, mineral, fatty acid

\section{INTRODUCTION}

The World Health Organization (WHO, 2020) defines being overweight and obese as an excessive accumulation of fat which poses a health risk. The leading cause of obesity is an imbalance in caloric intake and calories expended, in addition to increased consumption of

\footnotetext{
*Corresponding author: Associate Professor Dr. Hasnah binti Haron Nutritional Sciences Programme, Centre for Health Aging and Wellness, Faculty of Health Sciences, Universiti Kebangsaan Malaysia, Kuala Lumpur, Malaysia

Tel: (6)(03)89215555

Email Address: hasnaharon@ukm.edu.my

doi: https: / /doi.org/10.31246/mjn-2020-0115
} 
energy-dense foods which are high in fat and sugar. Based on the National Health and Morbidity Survey (NHMS) 2019, one in two adults in Malaysia are overweight or obese. In addition, findings from both NHMS 2015 (IPH, 2015) and NHMS 2019 (IPH, 2019) have indicated that the obesity rate among women is higher than among men. Since overweight and obesity are correlated with increased risk of developing a broad range of non-communicable diseases, such as diabetes, cardiovascular diseases, cancers, and chronic respiratory diseases, public health authorities have identified the prevention of obesity as a high priority initiative to improve public health (WHO, 2020; Fukuda et al. 2016).

Obesity prevention initiatives around the world have focused primarily on two approaches: (1) encouraging healthy eating, with a focus on reducing energy intake through reducing total calories consumed from fats and sugars, while increasing portion of fruits, vegetables, and whole grains; and (2) increasing physical activity, by engaging in regular physical activity for about 150 minutes per week for adults (WHO, 2020). Jordan et al. (2010) showed that nutrition education could help in the adoption of a healthy eating lifestyle. Healthy foods are those that provide nutrients to sustain the body's well-being and retain energy. Water, carbohydrates, fat, protein, vitamins, and minerals are the key nutrients that make up a healthy and balanced diet.

In this study, laboratory analyses which include moisture, ash, lipid, protein, carbohydrate, mineral, and fatty acid analyses measure the actual levels of nutrients in foods, thus providing a high level of accuracy of the analyses. Moisture or water content of food is an essential constituent in the food composition databases. The variability of water content in foods affects its composition (Nielsen, 2017). Ash is an important part of proximate analysis, which comprises of inorganic residue remaining after water and organic matters have been removed by the heating process to obtain nutritional information. Proteins are important constituents of foods for different reasons. They are a major source of energy, as well as containing essential amino acids, which are essential to human health, but which the body cannot synthesise. Proteins are also the major structural components of many natural foods, often determining their overall texture, e.g., tenderness of meat or fish products. Lipids, proteins, and carbohydrates constitute the main structural components of foods. An accurate and precise analysis of lipids in foods is important for accurate nutritional labelling, meeting manufacturing specifications, and determining whether a food meets the standard of identity (Nielsen, 2017). Mineral element determination in human diets is very important for human health, due to the presence of essential and toxic elements in foods or their incorporation in the manipulation of cooking process.

This study hypothesised that improving diet by modifying meal ingredients to contain less calories, fat, sodium, and sugar, while increasing fibre may be among the most effective strategies for weight management in obese and overweight individuals. Nutrition information provided in recipe books are useful for the public to get information on healthy nutrition and further prevent obesity. Therefore, this study was conducted to determine the calorie and nutrient compositions of modified recipes from selected cuisines listed in the healthy recipe book Mudah, Sihat, Sedap that was used in the Fit, Eat, Active, Training (F.E.A.T) programme. 


\section{MATERIALS AND METHODS}

The study protocol was approved by the Research Ethics Committee of Universiti Kebangsaan Malaysia (UKM PPI/111/8/ JEP-2016-392). All research participants gave their permission to be part of the study and signed the informed consent form to participate. The food preferences of participants for breakfast, lunch and dinner were collected in Malacca. Malacca was selected as the study location since it had the second highest prevalence of obesity in Malaysia prior to the implementation of the study (IPH, 2015). Although Wilayah Persekutuan Putrajaya showed the highest prevalence of obesity in Malaysia at that time $(43 \%)$, it was however not selected as the research area of choice because of logistic consideration by the research team.

The interview questions comprised of the participants' food preferences and favourite foods. This was to identify eating habits, most frequently consumed foods, and foods usually prepared at home. The 23 overweight and obese respondents provided the names of 41 types of foods which were then modified into healthier cuisines (Table 1) using the Nutritionist Pro $^{\mathrm{TM}}$ software (Axxya Systems, United States), and thereafter prepared by professional chefs. The preferred cuisines reported by the respondents was part of the needs assessment results (Table 1) prior to the development of recipe book and implementation of the F.E.A.T programme. Another 12

Table 1. List of food preferences by respondents

\begin{tabular}{llcc}
\hline Meal time & Top five foods preferred & $n$ & $\begin{array}{c}\text { Percentage of foods } \\
\text { mentioned (\%) }\end{array}$ \\
\hline Breakfast $(n=46)$ & Nasi Lemak & 8 & 17.4 \\
& Fried Rice & 7 & 15.2 \\
& Biscuits & 5 & 10.9 \\
& Bread & 5 & 10.9 \\
& Fried Noodle & 5 & 10.9 \\
Lunch $(n=52)$ & Asam Pedas & 10 & 21.7 \\
& Masak Sambal/Pedas & 10 & 21.7 \\
& Ikan/Ayam Masak Lemak & 6 & 11.5 \\
& Stir-fried Vegetables & 5 & 9.6 \\
Afternoon tea $(n=24)$ & 5 & 9.6 \\
& Curry & & 37.5 \\
& Banana Fritters & 9 & 16.7 \\
& Cekodok & 4 & 16.7 \\
& Bread & 4 & 12.5 \\
Biscuits & 3 & 4.1 \\
Others & 1 & \\
& & & 17.6 \\
Dinner $(n=34)$ & Asam Pedas & 6 & 17.6 \\
& Ikan/Ayam Masak Lemak & 6 & 14.7 \\
Masak Sambal/Pedas & 5 & 8.8 \\
Noodle-based cuisines & 3 & 5.9 \\
Curry & 2 &
\end{tabular}


low calorie juices were developed by nutritionists using sources of fruits and vegetables, which contained less sugar. Sensory analysis comprising of attributes like taste, smell and texture of the cuisines was conducted among all nutritionists, research team members and chefs following the preparation of these modified recipes.

This paper focuses on the proximate analysis of foods listed in the recipe book. The study design was laboratory analysis based on standard methods. This study only reported the food analysis of the modified recipes. The food intake of the respondents is reported in the effectiveness of the F.E.A.T programme and is published elsewhere.

\section{Sample preparation}

The recipe book consisted of recipes for 48 dishes and 12 types of beverages. All recipes were modified to be healthier, by using cooking methods, such as steaming, shallow frying, boiling, baking, or no usage of oil at all, instead of deep frying, substituting coconut milk with low fat milk or yoghurt, reducing use of sugar, increasing use of high fibre ingredients such as atta flour instead of wheat flour, and preparing juices using fruits, low fat milk, vegetables, oats and honey or raisins instead of sugar as shown in Table 1. The cuisines were prepared at two different times and had 4 replicates for proximate and mineral analyses; 14 recipes that included yoghurt and low-fat milk as ingredients were prepared in duplicates for fatty acids analysis. All samples were weighed per serving and recorded (Table 2). The samples were homogenised, stored in labelled containers and kept at $-20^{\circ} \mathrm{C}$ prior to analysis.

\section{Chemical analysis}

Moisture content

The moisture content of the food and beverage samples was determined according to the oven drying method introduced by the Association of Official Analytical Chemists (AOAC) (2007). According to this method, moisture content was reported as the difference between the weight of a sample before and after drying. The edible portion of the food was separated and homogenised using a blender. Approximately $5 \mathrm{~g}$ of sample was weighed and dried overnight at $105^{\circ} \mathrm{C}$ until constant weight was obtained.

\section{Total ash content}

The ash content of all the samples were determined according to a method provided by AOAC (2007). The ash content of the sample symbolised the inorganic residue after burning of the organic matter. A porcelain crucible with its lid was pre-ignited overnight at around $450-550^{\circ} \mathrm{C}$ in a muffle furnace, cooled in a desiccator, and weighed after it reached room temperature. Approximately $5 \mathrm{~g}$ of sample was weighed and placed on a hot plate until the sample has turned black and no smoke was produced. The crucibles were then placed in the furnace at $550^{\circ} \mathrm{C}$ overnight.

\section{Crude protein content}

The crude protein content of all the samples were determined according to the Kjehdahl method by AOAC (2007) using a Kjeltec System 2200 Distilling Unit (Foss Tecator, Hoganas, Sweden). The Kjeldahl method involves the digestion of food with a strong acid so that nitrogen is released, which is then quantified using a titration technique. Protein quantity is then calculated from the nitrogen concentration of the food using a conversion factor (usually 6.25, which is equivalent to $0.16 \mathrm{~g}$ nitrogen per gram of protein). Approximately $2 \mathrm{~g}$ of sample was placed into the digestion tubes. Potassium sulphate and copper sulphate were added into each digestion tube as catalyst. About $12 \mathrm{ml}$ of 
concentrated sulphuric acid $\left(\mathrm{H}_{2} \mathrm{SO}_{4}\right)$ was carefully added to the digestion tube, which was then gently shaken. The digestion procedure was performed using pre-heated $\left(420^{\circ} \mathrm{C}\right)$ digestion block for 60 minutes until a clear green solution was obtained. The digested sample was then cooled for 30 minutes. The distillation procedure was then performed using the distillation unit of Kjeltec 2200. Boric acid mixture was titrated with $0.2 \mathrm{~N}$ hydrochloric acid $(\mathrm{HCl})$ until the colour changed to that of the indicator. The volume of acid required in the titration was recorded.

\section{Crude fat content}

The fat content in all the samples were determined according to the Soxhlet method by AOAC (2007), using the 2055 Soxtec Avanti Manual System, Foss Tecator, Sweden. Soxhlet method is a traditional technique used for extracting lipids in foods, whereby the sample is grounded into small particles, and placed into a porous thimble. Mainly it has three compartments - flask, extraction chamber, and condenser. The sample is placed in a thimble and once the flask is heated, the solvent is evaporated and will move up to the condenser, where it is converted into a liquid and collected into the extraction chamber containing the sample. When the solvent passes through the sample, it extracts the fats and carries them into the flask. After completion of the extraction, the solvent is evaporated, and the mass of lipid remaining is measured and used for analysis (Nielsen, 2017). The instrument uses a solution of $40-60 \%$ petroleum ether to extract the fat in the samples. Initially, samples of foods $(3 \mathrm{~g})$ and beverages $(5 \mathrm{~g})$ were weighed and placed in the thimbles. About 2-3 spatulas of celite were mixed with samples of beverages before being heated in a water bath for two (2) hours. The samples were then homogenised with sodium sulphate before being transferred to the thimbles for fat extraction. When the extraction process had completed, extraction cups were dried in the oven at $100^{\circ} \mathrm{C}$ for 15 minutes. The extraction cups were left to cool in the desiccator and they were reweighed until consistent weight has been reached. The fat content was calculated in percentage based on initial sample weight.

\section{Carbohydrate content}

Carbohydrate content was calculated using the formula [Carbohydrate $=100$ $\%-\%$ (moisture + ash + crude protein + fat)] (Merrill \& Watt, 1973).

\section{Calorie content}

The number of grams of carbohydrate, protein, and fat were multiplied by 4,4 , and 9 , respectively and the values were added, based on the Atwater general factors and reported in the unit of $\mathrm{kcal}$ (Atwater \& Bryant, 1900).

\section{Mineral content}

Mineral compositions (sodium, potassium, calcium, magnesium, iron, and zinc) were analysed using ash obtained during ash analysis (AOAC, 2007). These minerals were chosen due to their important roles and benefits to the human body (Gharibzahedi \& Jafari, 2017). Approximately $5 \mathrm{ml}$ of concentrated hydrochloric acid was poured into the crucibles containing ash to dissolve the samples. The crucibles were then placed in a hot water bath until the samples dried. About $2 \mathrm{ml}$ of concentrated hydrochloric acid was then added to dissolve the leftover residue. Distilled water was added next into the crucibles and then the solution was poured into a volumetric flask for filtration process. Following that, the solution was cooled to room temperature, and deionised water was added until the solution reached $100 \mathrm{ml}$. Ash solutions were then analysed using Atomic 
Absorption Spectrophotometer (Analyst 400, Perkin Elmer, United States) and a calibration curve was prepared for each analysed mineral using the standard solutions prepared.

\section{Fatty acids composition}

Fatty acids were extracted from the samples using the standard method of International Union of Pure and Applied Chemistry (IUPAC) 2.301 (1987) at an accredited food analysis laboratory. The profiling was done using gas chromatography equipped with a fluorescent ion detector (GC-FID). The FAMEs were identified by comparing their relative and absolute retention times. Fatty acids composition was reported as a relative percentage of the total peak area.

\section{Statistical analysis}

Data were analysed using the SPSS version 22.0 (SPSS Inc., Chicago, II, USA) software. Descriptive analysis, in the form of mean and standard deviations, was used to present the data. Analysis of variance (ANOVA) test was used to compare differences in the means of moisture content, ash content, crude protein content, carbohydrate content, fat content, and mineral content of food and beverage samples. After performing an ANOVA, a post-hoc test (Tukey's Honestly Significant Difference, Tukey's HSD) was conducted to determine the differences between the groups.

\section{RESULTS AND DISCUSSION}

Table 2 shows the comparison of calorie content between the original recipes based on estimation and laboratory analysis results of modified recipes for each cuisine. Based on the laboratory analysis, all 41 dishes showed lower calories after modifications compared to the original recipes, except for Kobis Goreng and Sambal Ikan Bilis. Another seven dishes created by nutritionists showed calorie values of within 47 to 295 $\mathrm{kcal} / 100 \mathrm{~g}$; for juices, the calories were within 12 to $49 \mathrm{kcal} / 100 \mathrm{~g}$. Total calories for healthy juices analysed in this study were $<50 \mathrm{kcal} / 100 \mathrm{~g}$ and this result is consistent with the study conducted by Hegde, Adhikari \& D'Souza (2013), which stated that fruits, such as lemon, orange, apple, and papaya, are low in calories. The energy value for Kobis Goreng after modification was found to be higher (305 kcal/100g) compared to the original recipe (205 $\mathrm{kcal} / 100 \mathrm{~g})$. This might be due to the presence of fried soya bean curd (220 kcal/100g) and dried salted prawn (229 kcal/100g) in the modified recipe. For Sambal Ikan Bilis, the calorie content after modification (178 kcal/100g) was found to be nearly the same with estimation of the original recipe (170 $\mathrm{kcal} / 100 \mathrm{~g})$, however the value was lower compared to that reported in the Malaysian Food Composition Database (MyFCD) (316 $\mathrm{kcal} / 100 \mathrm{~g})$. Laboratory analysis results showed that for vegetable dishes, Kobis Goreng had significantly the highest $(p<0.05)$ amount of calories $(305$ kcal/100g), followed by Kerabu Telur for meat and poultry cuisines (295 $\mathrm{kcal} / 100 \mathrm{~g})$. In the fish and seafood category, Asam Pedas Tenggiri and Sambal Udang had the highest number of calories $(221 \mathrm{kcal} / 100 \mathrm{~g}$ and 129 $\mathrm{kcal} / 100 \mathrm{~g}$, respectively) due to the high fat content in both recipes. The high fat content in Cucur Ikan Bilis was the major contributor to the total calories in that recipe (261 kcal/100g). This was due to the use of atta flour (358 kcal/100g) and anchovies (264 kcal/100g), which contributed a fair amount of calories to this recipe (MyFCD).

\section{Moisture and total ash content}

Table 3 showed that Jus Labu Bersusu had the highest $(p<0.05)$ moisture 
Table 2. List of cuisines and beverages from the recipe book [Cont'd]

\begin{tabular}{|c|c|c|c|c|c|}
\hline \multirow[b]{2}{*}{ Local name } & \multirow[b]{2}{*}{ Common name } & \multirow[b]{2}{*}{ Modification made } & \multicolumn{2}{|c|}{$\begin{array}{c}\text { Calorie content } \\
\text { (kcal/100g) }\end{array}$} & \multirow[b]{2}{*}{$\begin{array}{l}\text { Weigh per } \\
\text { serving }\end{array}$} \\
\hline & & & $\begin{array}{l}\text { Original } \\
\text { recipe }\end{array}$ & $\begin{array}{l}\text { Modified } \\
\text { recipe }\end{array}$ & \\
\hline $\begin{array}{l}\text { Masak Lemak } \\
\text { Labu Kuning }\end{array}$ & $\begin{array}{l}\text { Pumpkin cooked } \\
\text { in low fat milk }\end{array}$ & $\begin{array}{l}\text { Substituted coconut } \\
\text { milk with natural } \\
\text { yoghurt }\end{array}$ & 359 & 63 & 85 \\
\hline Pajeri Nenas & $\begin{array}{l}\text { Pineapple cooked } \\
\text { in yoghurt }\end{array}$ & $\begin{array}{l}\text { 1. Substituted } \\
\text { coconut milk with } \\
\text { natural yoghurt } \\
\text { 2. No sugar added } \\
\text { 3. Used olive oil }\end{array}$ & 599 & 80 & 108 \\
\hline $\begin{array}{l}\text { Kacang Buncis } \\
\text { Goreng }\end{array}$ & $\begin{array}{l}\text { Fried green } \\
\text { beans }\end{array}$ & $\begin{array}{l}\text { 1. Reduced quantity of } \\
\text { oil used } \\
2 \text {. Used olive oil }\end{array}$ & 146 & 64 & 74 \\
\hline $\begin{array}{l}\text { Masak Lemak } \\
\text { Sayur Campur }\end{array}$ & $\begin{array}{l}\text { Mixed vegetables } \\
\text { cooked in low fat } \\
\text { milk }\end{array}$ & $\begin{array}{l}\text { 1. Substituted } \\
\text { coconut milk with low } \\
\text { fat milk } \\
2 \text {. Added soy bean } \\
\text { curd (tempe) }\end{array}$ & 391 & 213 & 101 \\
\hline $\begin{array}{l}\text { Masak Lemak } \\
\text { Jantung } \\
\text { Pisang }\end{array}$ & $\begin{array}{l}\text { Banana flower } \\
\text { cooked in low fat } \\
\text { milk }\end{array}$ & $\begin{array}{l}\text { 1. Substituted } \\
\text { coconut milk with low } \\
\text { fat milk } \\
\text { 2. Added carrot }\end{array}$ & 555 & 219 & 56 \\
\hline Pajeri Terung & $\begin{array}{l}\text { Brinjal cooked in } \\
\text { yoghurt }\end{array}$ & $\begin{array}{l}\text { 1. Used brown sugar } \\
2 . \text { Reduced quantity of } \\
\text { oil used }\end{array}$ & 287 & 154 & 65 \\
\hline $\begin{array}{l}\text { Tomyam } \\
\text { Campur }\end{array}$ & Mixed tomyam & $\begin{array}{l}\text { Used boiling method } \\
\text { instead of stir frying }\end{array}$ & 135 & 55 & 66 \\
\hline $\begin{array}{l}\text { Masak Lemak } \\
\text { Nangka }\end{array}$ & $\begin{array}{l}\text { Jackfruit cooked } \\
\text { in low fat milk }\end{array}$ & $\begin{array}{l}\text { 1. Substituted } \\
\text { coconut milk with low } \\
\text { fat milk } \\
2 \text {. Added celery and } \\
\text { tomato }\end{array}$ & 266 & 94 & 61 \\
\hline $\begin{array}{l}\text { Masak Lemak } \\
\text { Telur Itik }\end{array}$ & $\begin{array}{l}\text { Duck egg cooked } \\
\text { in low fat milk }\end{array}$ & $\begin{array}{l}\text { Substituted coconut } \\
\text { milk with low fat milk }\end{array}$ & 273 & 96 & 71 \\
\hline Kari Ayam & Chicken curry & $\begin{array}{l}\text { 1. No sugar added } \\
\text { 2. Substituted } \\
\text { coconut milk with } \\
\text { natural yoghurt } \\
\text { 3. Added carrot and } \\
\text { tomato }\end{array}$ & 237 & 119 & 83 \\
\hline
\end{tabular}


Table 2. List of cuisines and beverages from the recipe book [Cont'd]

\begin{tabular}{|c|c|c|c|c|c|}
\hline \multirow[b]{2}{*}{ Local name } & \multirow[b]{2}{*}{ Common name } & \multirow[b]{2}{*}{ Modification made } & \multicolumn{2}{|c|}{$\begin{array}{c}\text { Calorie content } \\
\text { (kcal/100g) }\end{array}$} & \multirow[b]{2}{*}{$\begin{array}{l}\text { Weigh per } \\
\text { serving }\end{array}$} \\
\hline & & & $\begin{array}{l}\text { Original } \\
\text { recipe }\end{array}$ & $\begin{array}{l}\text { Modified } \\
\text { recipe }\end{array}$ & \\
\hline Kari Daging & Beef curry & $\begin{array}{l}\text { 1. Substituted } \\
\text { coconut milk with } \\
\text { natural yoghurt } \\
\text { 2. Reduced quantity } \\
\text { of oil used } \\
\text { 3. No sugar added }\end{array}$ & 355 & 182 & 89 \\
\hline $\begin{array}{l}\text { Daging Masak } \\
\text { Kicap }\end{array}$ & $\begin{array}{l}\text { Beef cooked in } \\
\text { soy sauce }\end{array}$ & $\begin{array}{l}\text { 1. Added carrot } \\
\text { 2. Reduced quantity } \\
\text { of oil used } \\
\text { 3. No sugar added }\end{array}$ & 258 & 119 & 95 \\
\hline $\begin{array}{l}\text { Ayam Masak } \\
\text { Kicap }\end{array}$ & $\begin{array}{l}\text { Chicken cooked } \\
\text { in soy sauce }\end{array}$ & $\begin{array}{l}\text { 1. Reduced quantity } \\
\text { of oil used } \\
\text { 2. Substituted tomato } \\
\text { sauce with fresh } \\
\text { tomato }\end{array}$ & 344 & 111 & 93 \\
\hline $\begin{array}{l}\text { Ayam Masak } \\
\text { Sambal }\end{array}$ & $\begin{array}{l}\text { Chicken cooked } \\
\text { in chilli paste }\end{array}$ & $\begin{array}{l}\text { 1. Roasted the } \\
\text { chicken instead of } \\
\text { frying } \\
2 . \text { Reduced quantity } \\
\text { of oil used }\end{array}$ & 383 & 122 & 90 \\
\hline Sambal Telur & $\begin{array}{l}\text { Egg cooked in } \\
\text { chilli paste }\end{array}$ & $\begin{array}{l}\text { 1. Reduced quantity } \\
\text { of oil used. } \\
\text { 2. Added tomato and } \\
\text { peas } \\
\text { 3. Tomato sauce not } \\
\text { used }\end{array}$ & 288 & 104 & 64 \\
\hline $\begin{array}{l}\text { Masak Lemak } \\
\text { Cili Api Ayam }\end{array}$ & $\begin{array}{l}\text { Chicken cooked } \\
\text { in low fat milk } \\
\text { with bird's eye } \\
\text { chilli }\end{array}$ & $\begin{array}{l}\text { 1. Substituted } \\
\text { coconut milk with low } \\
\text { fat milk } \\
\text { 2. Added Ulam Raja }\end{array}$ & 617 & 105 & 96 \\
\hline $\begin{array}{l}\text { Masak Lemak } \\
\text { Cili Api } \\
\text { Daging Salai }\end{array}$ & $\begin{array}{l}\text { Beef cooked in } \\
\text { low fat milk with } \\
\text { bird's eye chilli }\end{array}$ & $\begin{array}{l}\text { 1. Substituted } \\
\text { coconut milk with low } \\
\text { fat milk } \\
\text { 2. Added fern shoots }\end{array}$ & 157 & 100 & 80 \\
\hline $\begin{array}{l}\text { Ayam Bakar } \\
\text { Berempah }\end{array}$ & $\begin{array}{l}\text { Spiced roasted } \\
\text { chicken }\end{array}$ & $\begin{array}{l}\text { Roasted the chicken } \\
\text { instead of frying }\end{array}$ & 510 & 227 & 88 \\
\hline $\begin{array}{l}\text { Asam Pedas } \\
\text { Daging }\end{array}$ & $\begin{array}{l}\text { Beef cooked in } \\
\text { spicy sour sauce }\end{array}$ & $\begin{array}{l}\text { 1. Used olive oil } \\
\text { 2. Reduced quantity } \\
\text { of oil used }\end{array}$ & 268 & 161 & 94 \\
\hline
\end{tabular}


Table 2. List of cuisines and beverages from the recipe book [Cont'd]

\begin{tabular}{|c|c|c|c|c|c|}
\hline \multirow[b]{2}{*}{ Local name } & \multirow[b]{2}{*}{ Common name } & \multirow[b]{2}{*}{ Modification made } & \multicolumn{2}{|c|}{$\begin{array}{c}\text { Calorie content } \\
\text { (kcal/100g) }\end{array}$} & \multirow[b]{2}{*}{$\begin{array}{l}\text { Weigh per } \\
\text { serving }\end{array}$} \\
\hline & & & $\begin{array}{l}\text { Original } \\
\text { recipe }\end{array}$ & $\begin{array}{l}\text { Modified } \\
\text { recipe }\end{array}$ & \\
\hline $\begin{array}{l}\text { Masak Lemak } \\
\text { Cili Api Udang }\end{array}$ & $\begin{array}{l}\text { Prawns cooked } \\
\text { in low fat milk } \\
\text { with bird's eye } \\
\text { chilli }\end{array}$ & $\begin{array}{l}\text { 1. Substituted } \\
\text { coconut milk with low } \\
\text { fat milk } \\
2 \text {. Added roasted soy } \\
\text { bean curd } \\
\text { 3. Added string beans }\end{array}$ & 490 & 65 & 53 \\
\hline $\begin{array}{l}\text { Udang Masam } \\
\text { Manis }\end{array}$ & $\begin{array}{l}\text { Sweet and sour } \\
\text { prawn }\end{array}$ & $\begin{array}{l}\text { 1. Reduced quantity } \\
\text { of flour used } \\
\text { 2. Used shallow frying } \\
\text { instead of deep frying }\end{array}$ & 306 & 62 & 54 \\
\hline $\begin{array}{l}\text { Sotong Masak } \\
\text { Kicap }\end{array}$ & $\begin{array}{l}\text { Cuttlefish } \\
\text { cooked in soy } \\
\text { sauce }\end{array}$ & $\begin{array}{l}\text { 1. Reduced quantity } \\
\text { of oil used } \\
2 \text {. Added long beans } \\
\text { and spring onions }\end{array}$ & 210 & 94 & 57 \\
\hline $\begin{array}{l}\text { Sambal } \\
\text { Udang }\end{array}$ & $\begin{array}{l}\text { Prawns cooked } \\
\text { in chilli paste }\end{array}$ & $\begin{array}{l}\text { 1. Used coconut palm } \\
\text { sugar } \\
\text { 2. Shrimp paste not } \\
\text { used }\end{array}$ & 301 & 129 & 56 \\
\hline $\begin{array}{l}\text { Sambal } \\
\text { Sotong }\end{array}$ & $\begin{array}{l}\text { Cuttlefish } \\
\text { cooked in chilli } \\
\text { paste }\end{array}$ & $\begin{array}{l}\text { 1. Used coconut palm } \\
\text { sugar } \\
\text { 2. Reduced quantity } \\
\text { of oil used }\end{array}$ & 275 & 96 & 55 \\
\hline $\begin{array}{l}\text { Masak Lemak } \\
\text { Cili Api Ketam }\end{array}$ & $\begin{array}{l}\text { Crabs cooked in } \\
\text { low fat milk with } \\
\text { bird's eye chilli }\end{array}$ & $\begin{array}{l}\text { 1. Substituted } \\
\text { coconut milk with low } \\
\text { fat milk } \\
\text { 2. Added soy bean } \\
\text { curd and tomato }\end{array}$ & 545 & 103 & 81 \\
\hline $\begin{array}{l}\text { Masak Lemak } \\
\text { Sotong }\end{array}$ & $\begin{array}{l}\text { Cuttlefish } \\
\text { cooked in low fat } \\
\text { milk }\end{array}$ & $\begin{array}{l}\text { 1. Substituted } \\
\text { coconut milk with low } \\
\text { fat milk } \\
\text { 2. Added long beans }\end{array}$ & 388 & 99 & 56 \\
\hline Kari Sardin & Sardine curry & $\begin{array}{l}\text { 1. Reduced quantity } \\
\text { of oil used } \\
2 \text {. Added tomato and } \\
\text { peas }\end{array}$ & 318 & 120 & 61 \\
\hline Kari Ikan & Mackerel curry & $\begin{array}{l}\text { 1. Substituted } \\
\text { coconut milk with } \\
\text { natural yoghurt } \\
\text { 2. No sugar added } \\
\text { 3. Reduced quantity } \\
\text { of oil used } \\
\text { 4. Added brinjal }\end{array}$ & 242 & 76 & 67 \\
\hline
\end{tabular}


Table 2. List of cuisines and beverages from the recipe book [Cont'd]

\begin{tabular}{|c|c|c|c|c|c|}
\hline \multirow[b]{2}{*}{ Local name } & \multirow[b]{2}{*}{ Common name } & \multirow[b]{2}{*}{ Modification made } & \multicolumn{2}{|c|}{$\begin{array}{c}\text { Calorie content } \\
\text { (kcal/100g) }\end{array}$} & \multirow[b]{2}{*}{$\begin{array}{l}\text { Weigh per } \\
\text { serving }\end{array}$} \\
\hline & & & $\begin{array}{l}\text { Original } \\
\text { recipe }\end{array}$ & $\begin{array}{l}\text { Modified } \\
\text { recipe }\end{array}$ & \\
\hline $\begin{array}{l}\text { Masak Lemak } \\
\text { Cili Api } \\
\text { Tenggiri }\end{array}$ & $\begin{array}{l}\text { Mackerel cooked } \\
\text { in low fat milk } \\
\text { with bird's eye } \\
\text { chilli }\end{array}$ & $\begin{array}{l}\text { 1. Substituted } \\
\text { coconut milk with low } \\
\text { fat milk } \\
\text { 2. Added tomato }\end{array}$ & 506 & 165 & 95 \\
\hline $\begin{array}{l}\text { Sambal Ikan } \\
\text { Keli }\end{array}$ & $\begin{array}{l}\text { Catfish cooked } \\
\text { in chilli paste }\end{array}$ & $\begin{array}{l}\text { 1. Used olive oil } \\
\text { 2. Roasted the fish }\end{array}$ & 432 & 288 & 68 \\
\hline $\begin{array}{l}\text { Asam Pedas } \\
\text { Pari }\end{array}$ & $\begin{array}{l}\text { Stingray cooked } \\
\text { in spicy sour } \\
\text { sauce }\end{array}$ & $\begin{array}{l}\text { Reduced quantity of } \\
\text { oil used }\end{array}$ & 435 & 129 & 57 \\
\hline $\begin{array}{l}\text { Asam Pedas } \\
\text { Tenggiri }\end{array}$ & $\begin{array}{l}\text { Mackerel cooked } \\
\text { in spicy sour } \\
\text { sauce }\end{array}$ & $\begin{array}{l}\text { 1. Used olive oil } \\
\text { 2. Reduced quantity } \\
\text { of oil used }\end{array}$ & 417 & 221 & 61 \\
\hline $\begin{array}{l}\text { Ikan Selar } \\
\text { Bakar Berlada }\end{array}$ & $\begin{array}{l}\text { Roasted } \\
\text { yellowstripe scad }\end{array}$ & $\begin{array}{l}\text { 1. Roasted the } \\
\text { chicken instead of } \\
\text { frying } \\
2 \text {. Added carrot }\end{array}$ & 507 & 117 & 41 \\
\hline $\begin{array}{l}\text { Nasi Goreng } \\
\text { Cina }\end{array}$ & $\begin{array}{l}\text { Chinese fried } \\
\text { rice }\end{array}$ & $\begin{array}{l}\text { 1. Substituted usage } \\
\text { of oil with small } \\
\text { quantity of margerine } \\
2 \text {. Added carrot and } \\
\text { french beans }\end{array}$ & 442 & 105 & 250 \\
\hline $\begin{array}{l}\text { Cucur Ikan } \\
\text { Bilis }\end{array}$ & Anchovies fritter & $\begin{array}{l}\text { 1. Used atta flour } \\
\text { instead of wheat flour } \\
2 . \text { Reduced quantity } \\
\text { of oil used }\end{array}$ & 745 & 261 & 92 \\
\hline $\begin{array}{l}\text { Lempeng } \\
\text { Kelapa }\end{array}$ & $\begin{array}{l}\text { Coconut } \\
\text { pancake }\end{array}$ & $\begin{array}{l}\text { 1. Used atta flour } \\
\text { instead of wheat flour } \\
\text { 2. Added oats } \\
\text { 3. No oil added }\end{array}$ & 272 & 261 & 88 \\
\hline Lepat Pisang & $\begin{array}{l}\text { Steamed banana } \\
\text { packets }\end{array}$ & $\begin{array}{l}\text { 1. Reduced quantity } \\
\text { of wheat flour used } \\
2 \text {. Added more } \\
\text { banana }\end{array}$ & 385 & 133 & 96 \\
\hline $\begin{array}{l}\text { Mee Goreng } \\
\text { Mamak }\end{array}$ & Fried noodles & $\begin{array}{l}\text { 1. Used chicken } \\
\text { breast } \\
\text { 2. Reduced quantity } \\
\text { of oil used } \\
\text { 3. Fish cake not used } \\
\text { 4. Added roasted soy } \\
\text { bean curd }\end{array}$ & 720 & 149 & 134 \\
\hline Nasi Lemak & $\begin{array}{l}\text { Rice in low fat } \\
\text { milk }\end{array}$ & $\begin{array}{l}\text { Substituted coconut } \\
\text { milk with low fat milk }\end{array}$ & 472 & 144 & 230 \\
\hline
\end{tabular}


Table 2. List of cuisines and beverages from the recipe book [Cont'd]

\begin{tabular}{|c|c|c|c|c|c|}
\hline \multirow[b]{2}{*}{ Local name } & \multirow[b]{2}{*}{ Common name } & \multirow[b]{2}{*}{ Modification made } & \multicolumn{2}{|c|}{$\begin{array}{c}\text { Calorie content } \\
\text { (kcal/100g) }\end{array}$} & \multirow[b]{2}{*}{$\begin{array}{l}\text { Weigh per } \\
\text { serving }\end{array}$} \\
\hline & & & $\begin{array}{l}\text { Original } \\
\text { recipe }\end{array}$ & $\begin{array}{l}\text { Modified } \\
\text { recipe }\end{array}$ & \\
\hline $\begin{array}{l}\text { *Sambal Ikan } \\
\text { Bilis }\end{array}$ & $\begin{array}{l}\text { Anchovies } \\
\text { cooked in chilli } \\
\text { paste }\end{array}$ & $\begin{array}{l}\text { 1. Reduced quantity } \\
\text { of oil used } \\
2 \text {. Added petai }\end{array}$ & 170 & 178 & 44 \\
\hline *Kobis Goreng & Fried cabbage & $\begin{array}{l}\text { 1. Reduced quantity } \\
\text { of oil used } \\
\text { 2. Added long beans } \\
\text { 3. Added soy bean } \\
\text { curd and dried salted } \\
\text { prawn }\end{array}$ & 212 & 305 & 126 \\
\hline $\begin{array}{l}\text { Terung Bakar } \\
\text { Berlada }\end{array}$ & $\begin{array}{l}\text { Roasted chillied } \\
\text { eggplant }\end{array}$ & $\begin{array}{l}\text { Roasted the brinjal } \\
\text { instead of fried }\end{array}$ & $\begin{array}{c}\text { Not } \\
\text { applicable }\end{array}$ & 59 & 61 \\
\hline $\begin{array}{l}\text { Buncis Goreng } \\
\text { Halia }\end{array}$ & $\begin{array}{l}\text { Stir fried green } \\
\text { beans with } \\
\text { ginger and beef }\end{array}$ & $\begin{array}{l}\text { Reduced quantity of } \\
\text { oil used }\end{array}$ & $\begin{array}{l}\text { Not } \\
\text { applicable }\end{array}$ & 150 & 33 \\
\hline $\begin{array}{l}\text { Sup Siew Pak } \\
\text { Choy }\end{array}$ & Pak choi soup & Boiling method & $\begin{array}{c}\text { Not } \\
\text { applicable }\end{array}$ & 47 & 59 \\
\hline Kerabu Telur & $\begin{array}{l}\text { White egg with } \\
\text { salad }\end{array}$ & Egg yolk not added & $\begin{array}{c}\text { Not } \\
\text { applicable }\end{array}$ & 295 & 57 \\
\hline $\begin{array}{l}\text { Udang Masak } \\
\text { Brokoli }\end{array}$ & $\begin{array}{l}\text { Prawns cooked } \\
\text { with broccoli }\end{array}$ & $\begin{array}{l}\text { 1. Reduced quantity } \\
\text { of oil used } \\
\text { 2. Used olive oil }\end{array}$ & $\begin{array}{c}\text { Not } \\
\text { applicable }\end{array}$ & 94 & 78 \\
\hline $\begin{array}{l}\text { Botok-botok } \\
\text { Tenggiri }\end{array}$ & $\begin{array}{l}\text { Steamed } \\
\text { mackerel }\end{array}$ & Steaming method & $\begin{array}{c}\text { Not } \\
\text { applicable }\end{array}$ & 151 & 38 \\
\hline $\begin{array}{l}\text { Sup Ikan } \\
\text { Merah }\end{array}$ & $\begin{array}{l}\text { Red snapper } \\
\text { soup }\end{array}$ & Boiling method & $\begin{array}{c}\text { Not } \\
\text { applicable }\end{array}$ & 114 & 134 \\
\hline $\begin{array}{l}\text { Jus Anggur } \\
\text { Hitam }\end{array}$ & $\begin{array}{l}\text { Black grape } \\
\text { juice }\end{array}$ & $\begin{array}{l}\text { Used low fat milk, } \\
\text { fruits and honey }\end{array}$ & $\begin{array}{c}\text { Not } \\
\text { applicable }\end{array}$ & 49 & 250 \\
\hline $\begin{array}{l}\text { Jus Brokoli } \\
\text { Sedap }\end{array}$ & $\begin{array}{l}\text { Delicious } \\
\text { brocolli juice }\end{array}$ & $\begin{array}{l}\text { Used vegetables, } \\
\text { fruits and honey }\end{array}$ & $\begin{array}{c}\text { Not } \\
\text { applicable }\end{array}$ & 19 & 250 \\
\hline $\begin{array}{l}\text { Jus Buah } \\
\text { Campuran }\end{array}$ & Mixed fruit juice & $\begin{array}{l}\text { Used oats, fruits and } \\
\text { honey }\end{array}$ & $\begin{array}{c}\text { Not } \\
\text { applicable }\end{array}$ & 36 & 250 \\
\hline $\begin{array}{l}\text { Jus Buah } \\
\text { Campuran } \\
\text { Timun }\end{array}$ & $\begin{array}{l}\text { Mixed fruit with } \\
\text { cucumber juice }\end{array}$ & $\begin{array}{l}\text { Used fruits and } \\
\text { vegetables }\end{array}$ & $\begin{array}{c}\text { Not } \\
\text { applicable }\end{array}$ & 17 & 250 \\
\hline $\begin{array}{l}\text { Jus Epal dan } \\
\text { Oat }\end{array}$ & $\begin{array}{l}\text { Apple and oat } \\
\text { juice }\end{array}$ & $\begin{array}{l}\text { Used oats, fruits, } \\
\text { honey and raisin }\end{array}$ & $\begin{array}{c}\text { Not } \\
\text { applicable }\end{array}$ & 37 & 250 \\
\hline
\end{tabular}


Table 2. List of cuisines and beverages from the recipe book [Cont'd]

\begin{tabular}{|c|c|c|c|c|c|}
\hline \multirow[b]{2}{*}{ Local name } & \multirow[b]{2}{*}{ Common name } & \multirow[b]{2}{*}{ Modification made } & \multicolumn{2}{|c|}{$\begin{array}{c}\text { Calorie content } \\
\text { (kcal/100g) }\end{array}$} & \multirow[b]{2}{*}{$\begin{array}{l}\text { Weigh per } \\
\text { serving }\end{array}$} \\
\hline & & & $\begin{array}{l}\text { Original } \\
\text { recipe }\end{array}$ & $\begin{array}{l}\text { Modified } \\
\text { recipe }\end{array}$ & \\
\hline $\begin{array}{l}\text { Jus Epal } \\
\text { Lobak } \\
\text { Berhalia }\end{array}$ & $\begin{array}{l}\text { Apple, carrot } \\
\text { and ginger juice }\end{array}$ & $\begin{array}{l}\text { Used low fat milk, } \\
\text { fruits, vegetables and } \\
\text { honey }\end{array}$ & $\begin{array}{c}\text { Not } \\
\text { applicable }\end{array}$ & 35 & 250 \\
\hline Jus Hijau & Green juice & $\begin{array}{l}\text { Used vegetables and } \\
\text { fruits }\end{array}$ & $\begin{array}{c}\text { Not } \\
\text { applicable }\end{array}$ & 15 & 250 \\
\hline $\begin{array}{l}\text { Jus Labu } \\
\text { Bersusu }\end{array}$ & $\begin{array}{l}\text { Pumpkin juice } \\
\text { with milk }\end{array}$ & $\begin{array}{l}\text { Used low fat milk and } \\
\text { fruits }\end{array}$ & $\begin{array}{c}\text { Not } \\
\text { applicable }\end{array}$ & 12 & 250 \\
\hline $\begin{array}{l}\text { Jus Mangga } \\
\text { Oat }\end{array}$ & $\begin{array}{l}\text { Oat and mango } \\
\text { juice }\end{array}$ & $\begin{array}{l}\text { Used oats, fruits and } \\
\text { raisin }\end{array}$ & $\begin{array}{c}\text { Not } \\
\text { applicable }\end{array}$ & 19 & 250 \\
\hline $\begin{array}{l}\text { Jus } \\
\text { Sengkuang } \\
\text { Cina }\end{array}$ & $\begin{array}{l}\text { Water chestnut } \\
\text { juice }\end{array}$ & $\begin{array}{l}\text { Used fruits and } \\
\text { vegetables }\end{array}$ & $\begin{array}{c}\text { Not } \\
\text { applicable }\end{array}$ & 25 & 250 \\
\hline $\begin{array}{l}\text { Jus Tembikai } \\
\text { Susu }\end{array}$ & Honeydew juice & $\begin{array}{l}\text { Used low fat milk and } \\
\text { fruits }\end{array}$ & $\begin{array}{c}\text { Not } \\
\text { applicable }\end{array}$ & 28 & 250 \\
\hline Jus Pisang & Banana juice & $\begin{array}{l}\text { Used low fat milk, } \\
\text { fruits and honey }\end{array}$ & $\begin{array}{c}\text { Not } \\
\text { applicable }\end{array}$ & 26 & 250 \\
\hline
\end{tabular}

*Calories increment after modification was made

'Not applicable' indicates that the recipe was created by nutritionists.

content $(96.7 \%)$, followed by Jus Hijau (96.2\%), and Jus Buah Campuran Timun (95.8\%). These results are consistent with a study carried out by Slavin \& Lloyd (2012) that reported various commonly consumed fruits having high moisture content (around 61 to 89\%). High ash content is an indicator of high amount of minerals in foods. Ash content of most food samples analysed in this study was $<5 \%$, which is the normal range for most food samples (Pallab \& Amartya, 2012). In this study, only Sambal Ikan Bilis had significantly $(p<0.05)$ high total ash content of $>5 \%$. This result is consistent with the reported high amount of mineral content (sodium, potassium, and calcium) in 6-10 g size group of anchovies (Sankar et al., 2013).

\section{Crude protein content}

The crude protein content was further categorised into vegetables, meat and poultry, fish, seafood, breakfast and tea-time cuisines, and finally beverages. In the vegetable cuisines category, the amount of protein content $(10.1 \%)$ was significantly higher $(p<0.05)$ in Buncis Goreng Halia, followed by Masak Lemak Sayur Campur (6.77\%), and Tomyam Campur (5.91\%) as shown in Table 3. The high protein content in Buncis Goreng Halia was due to the meat used in that recipe (NCCFN, 2010). For meat and poultry recipes, Ayam Bakar Berempah $(30.0 \%)$ showed significantly highest $(p<0.05)$ protein content, followed by Kari Daging $(18.3 \%)$ and Sambal Ayam $(17.6 \%)$. As for fish recipes, Sambal Ikan 
Bilis contained significantly highest $(p<0.05)$ amount of protein $(18.4 \%)$, followed by Botok-Botok Tenggiri (18.1\%) and Asam Pedas Tenggiri (17.8\%). As for seafood cuisines, Masak Lemak Ketam Cili Api had significantly highest $(p<0.05)$ protein content (12.3\%). The results also showed that cuttlefish recipes such as Masak Lemak Sotong had the highest protein content $(8.7 \%)$, while Sotong Masak Kicap and Sambal Sotong both had $8.52 \%$ protein. However, protein values provided in the MyFCD and Singapore FCD for Sambal Sotong were $13.3 \%$ and $12.3 \%$, respectively. These values are consistent with those from studies conducted by Varadharajan \& Soundarapandian (2014), which found that protein content in cephalothorax of freshwater crab from South East Coast of India was $13.5 \%$. As for breakfast and tea-time recipes, Lempeng Kelapa showed significantly highest $(p<0.05)$ amount of protein, which was $9.4 \%$, followed by Cucur Ikan Bilis (9.1\%), which used atta flour. This was because, according to the protein content data from MyFCD, whole wheat flour (atta flour) normally used in Lempeng Kelapa and Cucur Ikan Bilis was moderately high in protein (10.6\%). Jus Tembikai Susu contained significantly highest $(p<0.05)$ amount of protein $(2.5 \%)$, while Jus Mangga Oat had the lowest protein content $(0.2 \% \%)$. These results are consistent with Slavin \& Lloyd (2012)'s study which reported that fruits are low in protein content $(0.5$ to $1.1 \%)$.

\section{Crude fat content}

As shown in Table 3 , in the vegetable cuisines category, Pajeri Terung contained significantly highest $(p<0.05)$ fat content $(14.3 \%)$, followed by Masak Lemak Jantung Pisang (7.2\%) and Pajeri Nenas (4.6\%). In the meat and poultry category, Ayam Bakar Berempah showed significantly highest $(p<0.05)$ fat content $(8.7 \%)$, besides Kari Ayam (6.2\%) and
Asam Pedas Daging (6.0\%). Among fish dishes, Asam Pedas Tenggiri had significantly highest $(p<0.05)$ fat content (15.5\%), followed by Sambal Ikan Bilis (10.8\%) and Masak Lemak Cili Api Tenggiri (10.5\%). For seafood cuisines, Sambal Udang showed significantly highest $(p<0.05)$ amount of fat $(9.5 \%)$, apart from Sambal Sotong (6.0\%) and Sotong Masak Kicap (5.8\%). In the breakfast and tea-time category, Cucur Ikan Bilis showed significantly highest $(p<0.05)$ fat content $(11.6 \%)$, followed by Mee Goreng (5.6\%) and Nasi Lemak $(3.8 \%)$. Recipes that involved frying in oil as a preparation method may result in high fat content. Nandita (2013) reported that using cooking methods such as steaming, boiling, and baking can reduce fat content in cooked foods. On the contrary, recipes that use frying method have higher fat content than recipes that use boiling method (Dora et al., 2018). However, changing the food preparation method can affect the flavour, texture, appearance, and nutritional quality of the cooked foods (America's Test Kitchen \& Crosby, 2012). Meanwhile, for beverages, Jus Epal Lobak Berhalia, Jus Buah Campuran, and Jus Pisang showed low fat content (less than 0.9\%). These results are supported by Slavin $\&$ Lloyd (2012)'s study which concluded that fruits contain low amount of fat.

\section{Total carbohydrate content}

In the vegetable cuisines category, Kobis Goreng had significantly highest $(p<0.05)$ amount of carbohydrates (64.9\%). This was due to the low fat and protein contents of this recipe, which affected its carbohydrate content. As for meat and poultry category, Kerabu Telur had significantly highest $(p<0.05)$ amount of carbohydrates $(64.1 \%)$, while Udang Masak Brokoli in the seafood cuisines category came second (6.3\%). In the fish category, Sambal Ikan Keli had 


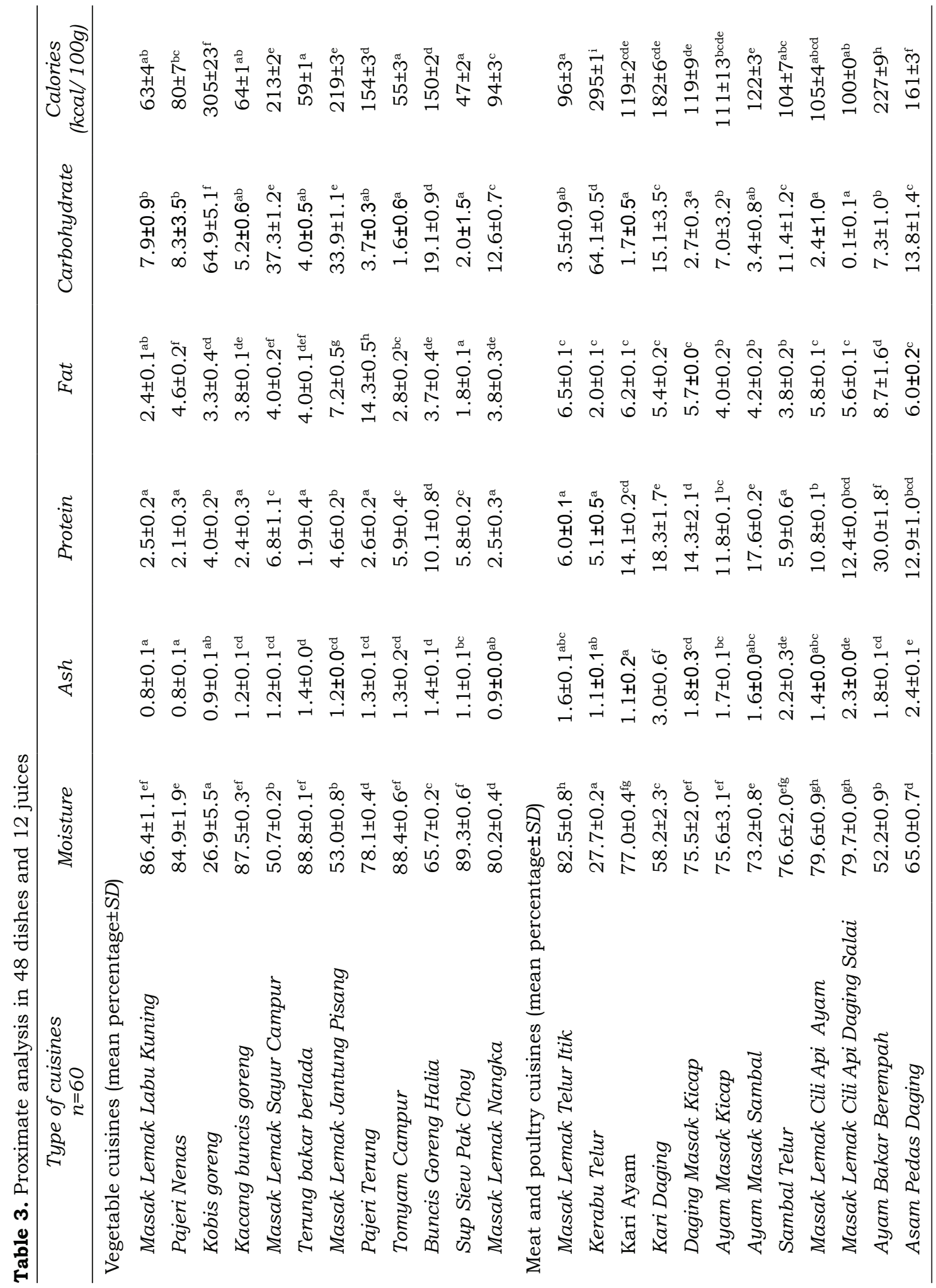




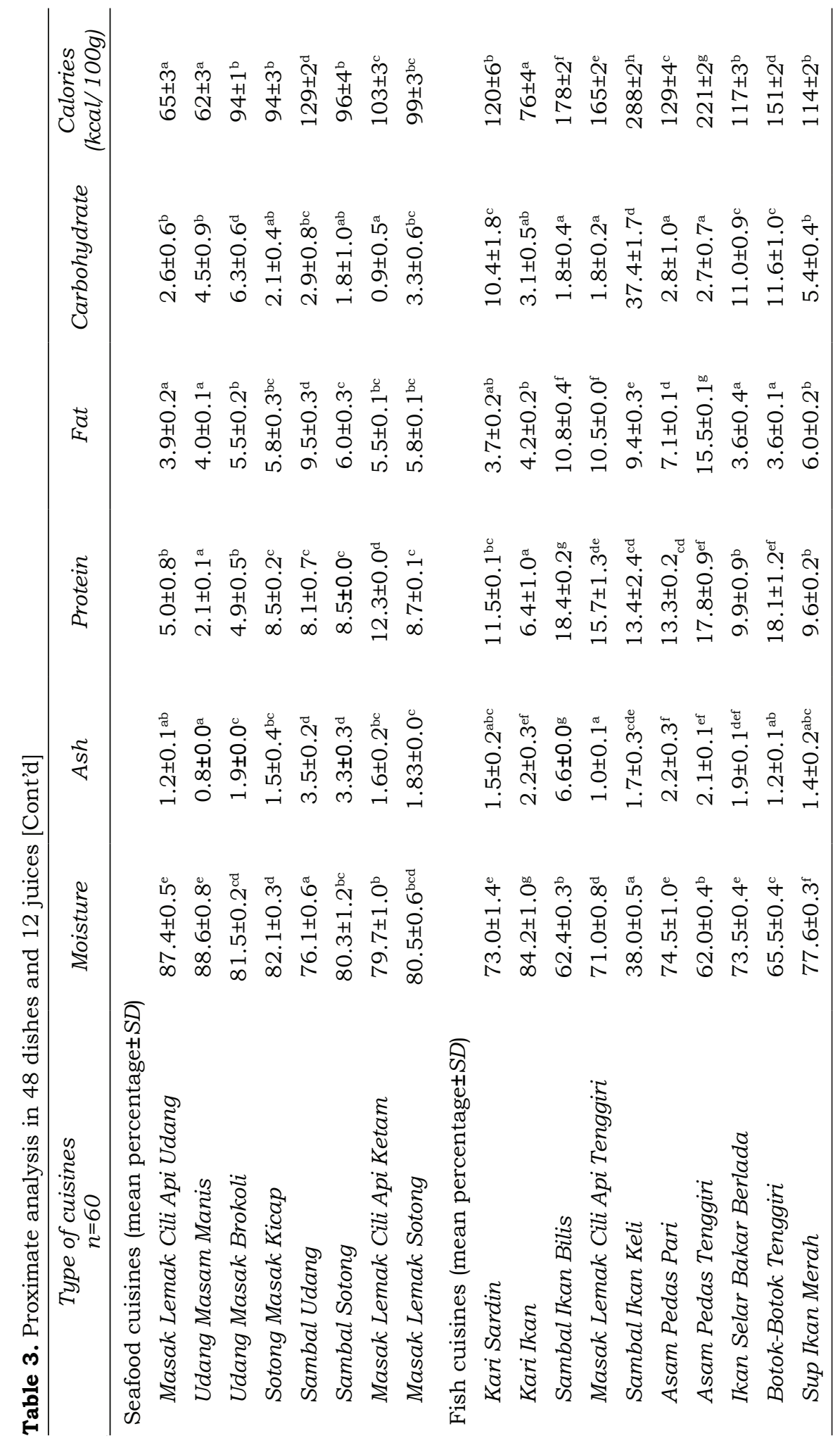




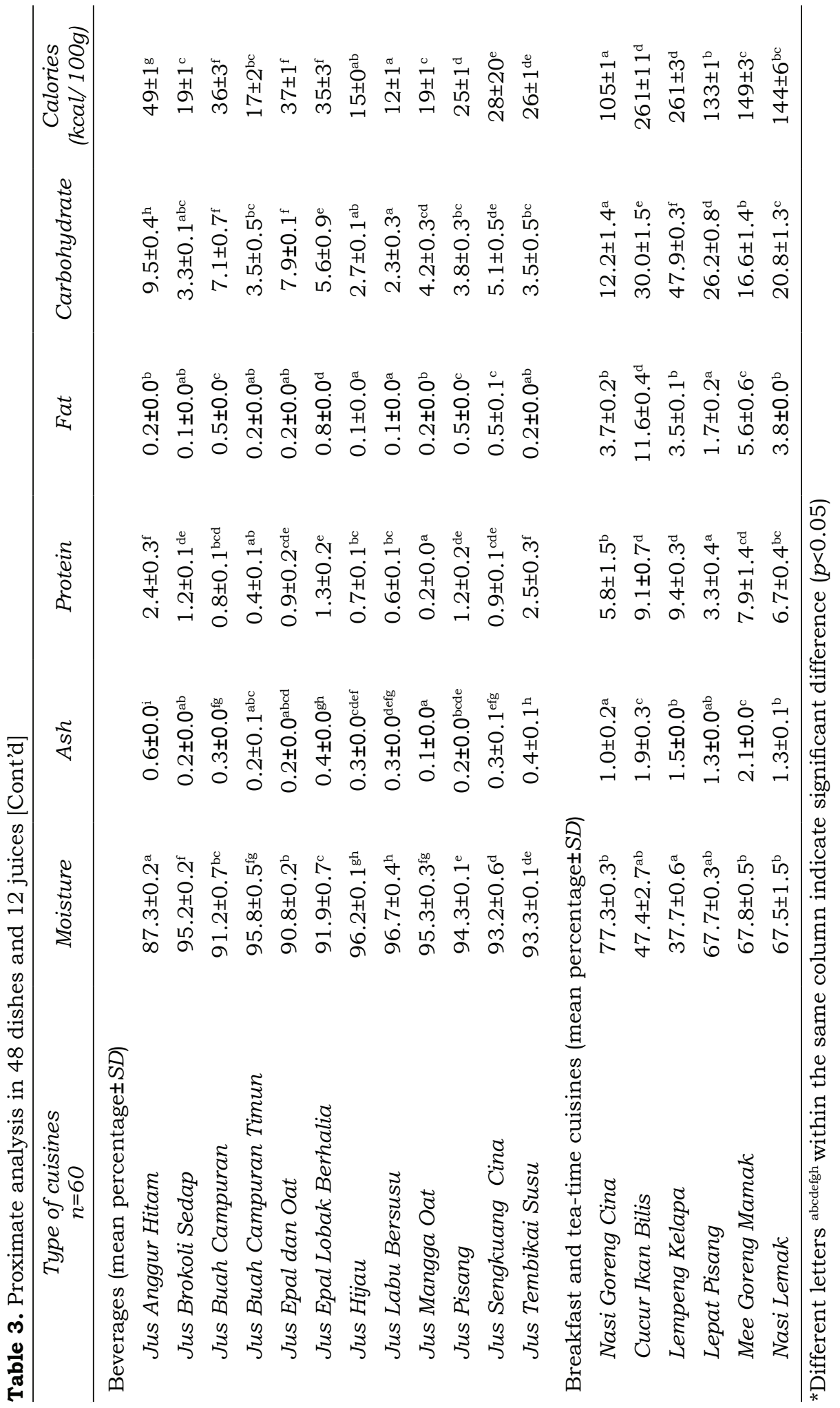


significantly highest $(p<0.05)$ amount of carbohydrates (37.4\%). As for breakfast and tea-time category, Lempeng Kelapa showed significantly highest $(p<0.05)$ amount of carbohydrates and this may be due to the atta flour and oats used in this recipe (47.9\%). MyFCD indicated that carbohydrate contents of atta flour and oats were $75.4 \%$ and $71.4 \%$, respectively. For juices, total carbohydrate content was not more than $10.0 \%$ and this could be due to the use of vegetables that were low in carbohydrates (MyFCD) such as cucumber, broccoli, pumpkin, water chestnut, carrot, ginger, pennywort, spinach, and celery together with fruits that have been mixed to form healthy juices.

\section{Mineral content}

Table 4 shows the mineral content in food samples. Meat cuisines were likely to have high sodium content. Asam Pedas Daging contained significantly highest $(p<0.05)$ amount of sodium (554 mg Na/100g). Most processed meat contained variable amount of sodium and are associated with high salt contents (McCance \& Widdowson's The Composition of Foods 2014). For potassium (K) content, Ayam Bakar Berempah showed significantly highest $(p<0.05)$ content across all categories (471 mg K/100g). Data in the MyFCD showed that chicken breast used in Ayam Bakar Berempah contained $313 \mathrm{mg}$ K/100g. Jus Buah Campuran (a mixture of fruits such as orange, pineapple and papaya together with oats and honey) contributed to a high amount of calcium (269 mg Ca/100g). Iron (Fe) content was significantly highest $(p<0.05)$ in Sambal Ikan Bilis (3.8 mg Fe/100g) within its category compared to the data in MyFCD (1.1 mg Fe/100g). This difference might be due to different sources of anchovies used for these studies as highlighted by Ehigiator \& Nwangwu (2011) that nutrient composition and biochemical properties of each organisms are different depending on the parts of animals, season, size, maturity, and natural habitat. In this study, Sambal Ikan Bilis has significantly highest $(p<0.05)$ amount of magnesium (Mg) (77 mg Mg/100g) across all categories. Sankar et al. (2013), who reported the magnesium content in three different anchovies showed that the magnesium content was between 10 to $30 \mathrm{mg} \mathrm{Mg} / 100 \mathrm{~g}$. Finally, Buncis Goreng Halia that used beef as one of its ingredient in the recipe had the highest $(p<0.05)$ amount of zinc $(\mathrm{Zn})(1.9 \mathrm{mg}$ $\mathrm{Zn} / 100 \mathrm{~g})$ compared to other cuisines. By comparing data from this study, it was reported in the International Zinc Nutrition Consultative Group IZiNCG (2004) that the amount of zinc content in beef is within $2.9-4.7 \mathrm{mg} \mathrm{Zn} / 100 \mathrm{~g}$.

\section{Fatty acids composition}

Based on Table 5, saturated fatty acid (SFA) was the most dominant fatty acid in yoghurt and low-fat dishes, followed by monounsaturated fatty acid (MUFA) and polyunsaturated fatty acid (PUFA). In Table 4, the highest amount of palmitic acid (42.3\%) was found in Masak Lemak Cili Api Ikan Tenggiri. These results are consistent with Manal's (2009) findings, which reported that Spanish mackerel (Scomberomorus maculatus) had high palmitic acid content. Next, the highest content of stearic acid (16.3\%) was found in Masak Lemak Sotong. Amonrat, Soottawat \& Wonnop (2006) reported that palmitic acid and stearic acid are abundant in the head and body of cuttlefish. For MUFA, oleic acid was found in all fourteen cuisines. Masak Lemak Telur Itik showed the highest amount of oleic acid (42.5\%) and this result is consistent with Vassilia et al. (2011)'s study, which showed that duck eggs contain high composition of oleic acid and linoleic acid, compared to saturated and polyunsaturated fatty acids. After oleic acid, palmitoleic 


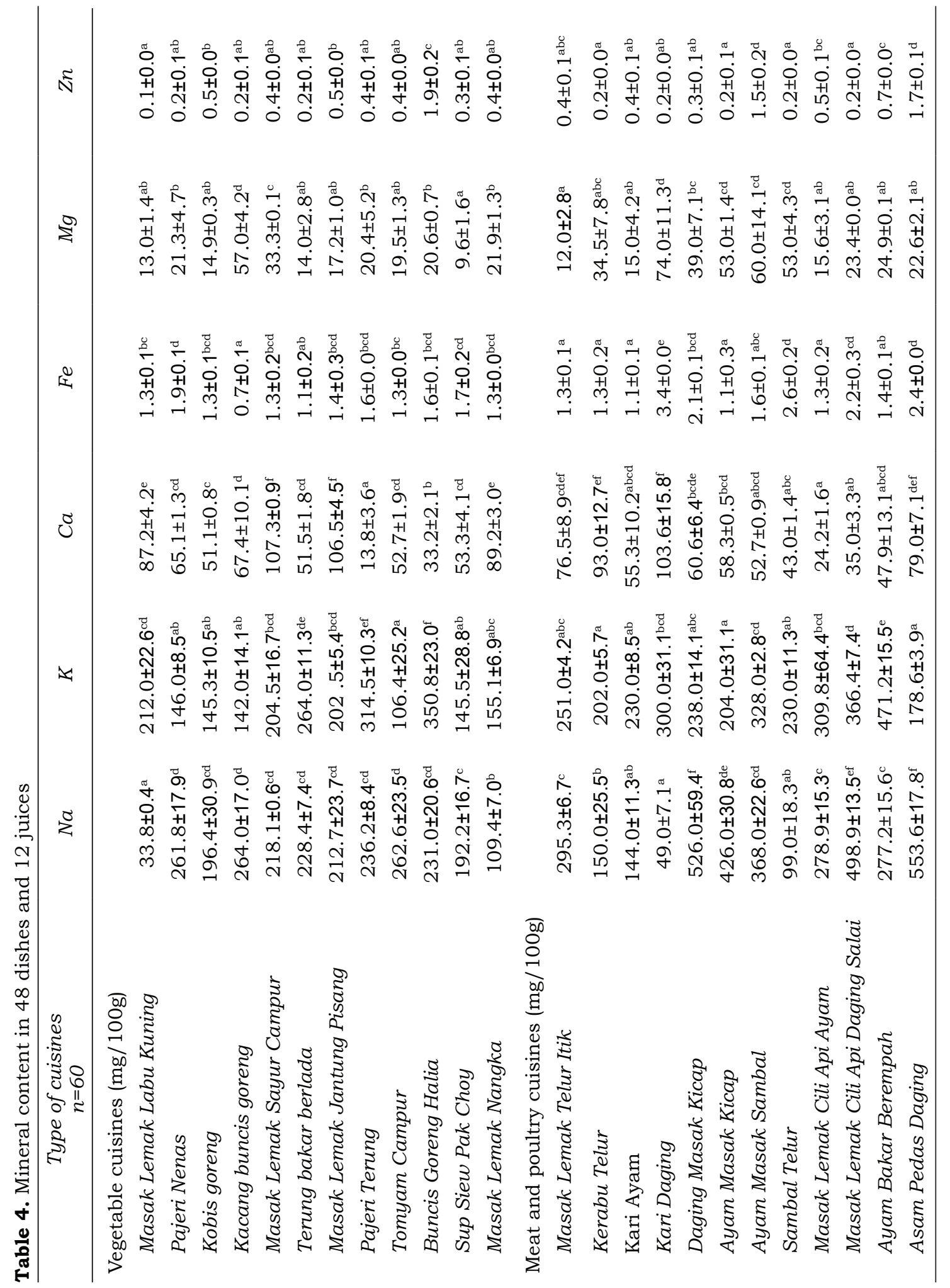




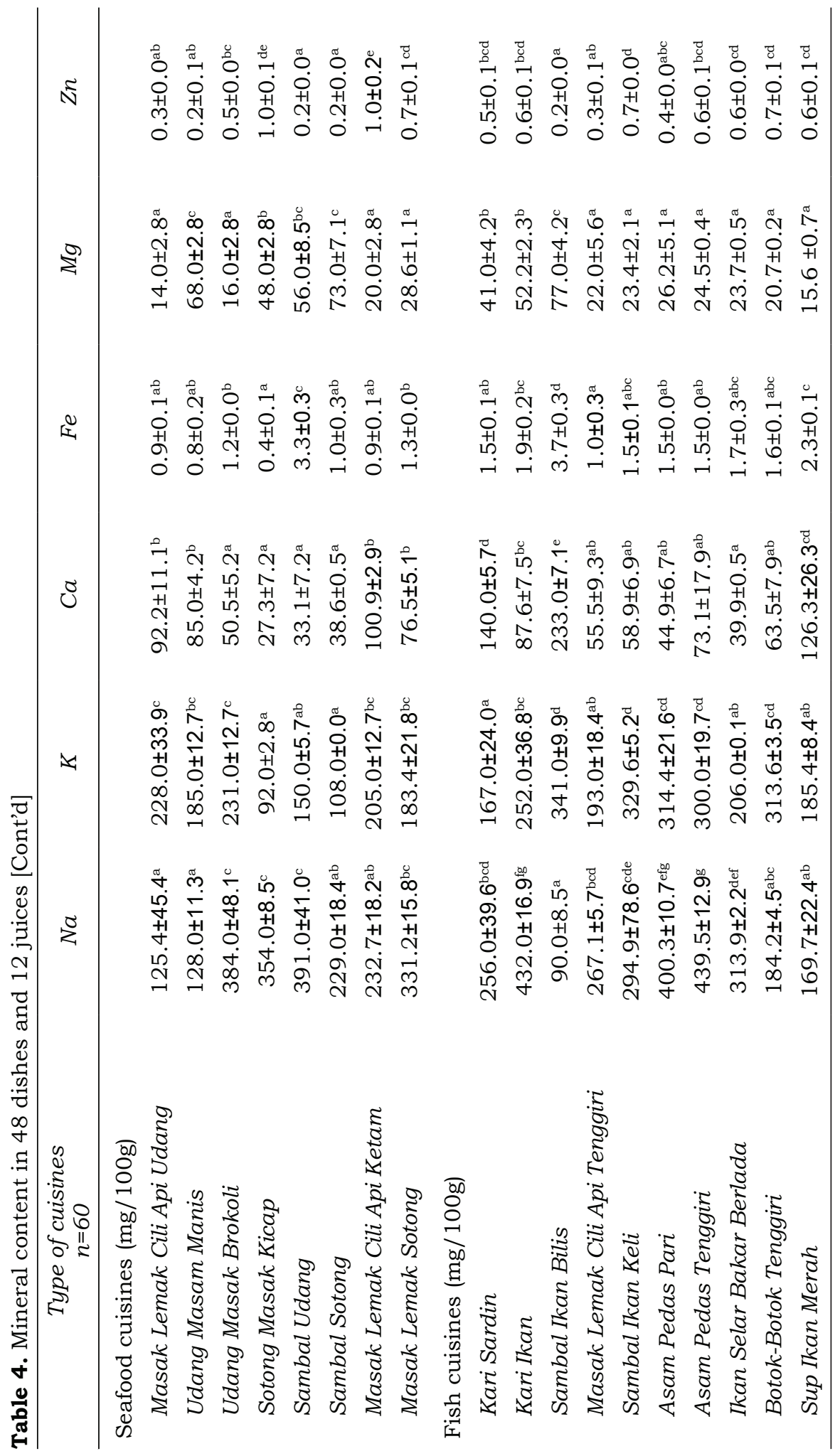




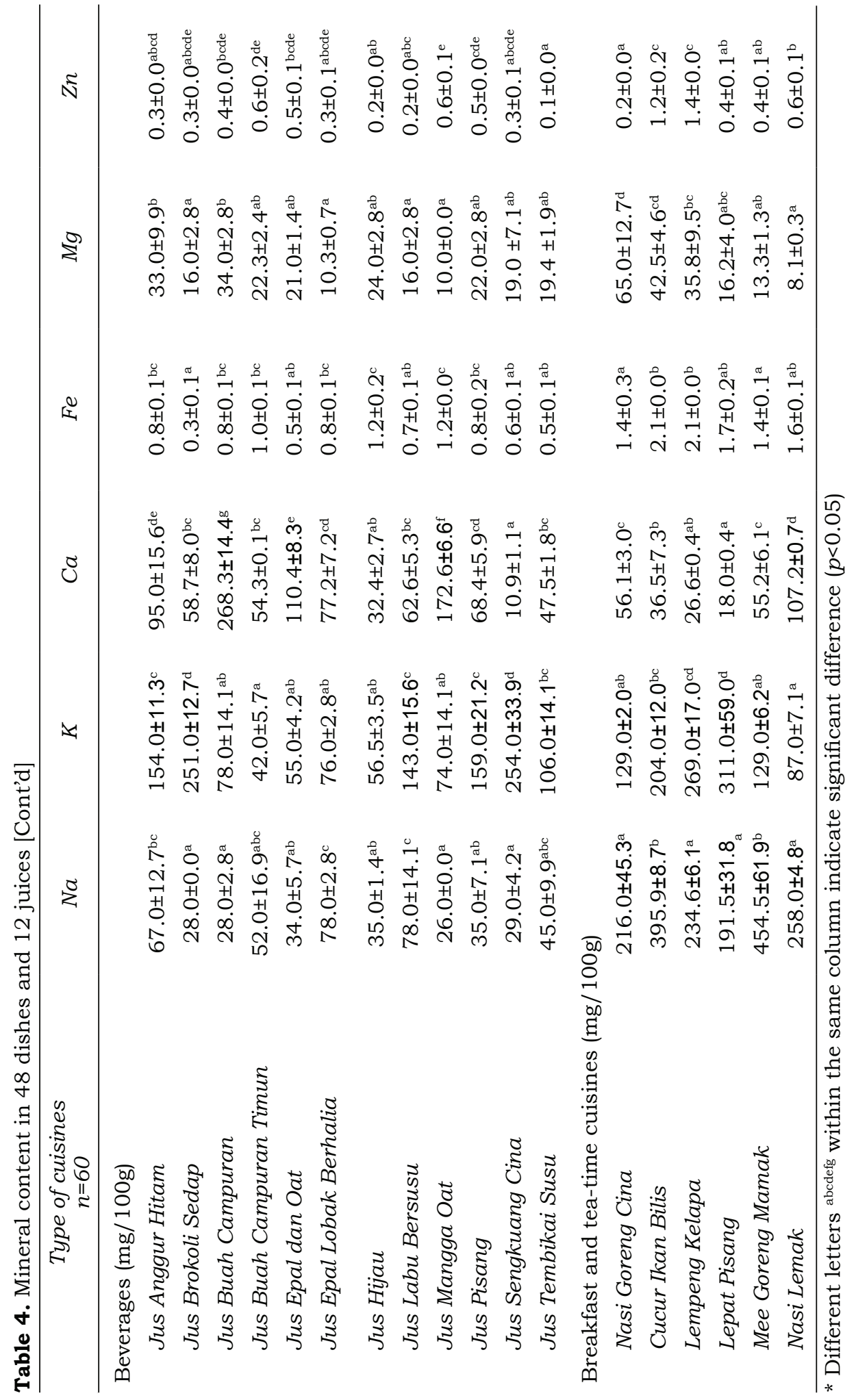




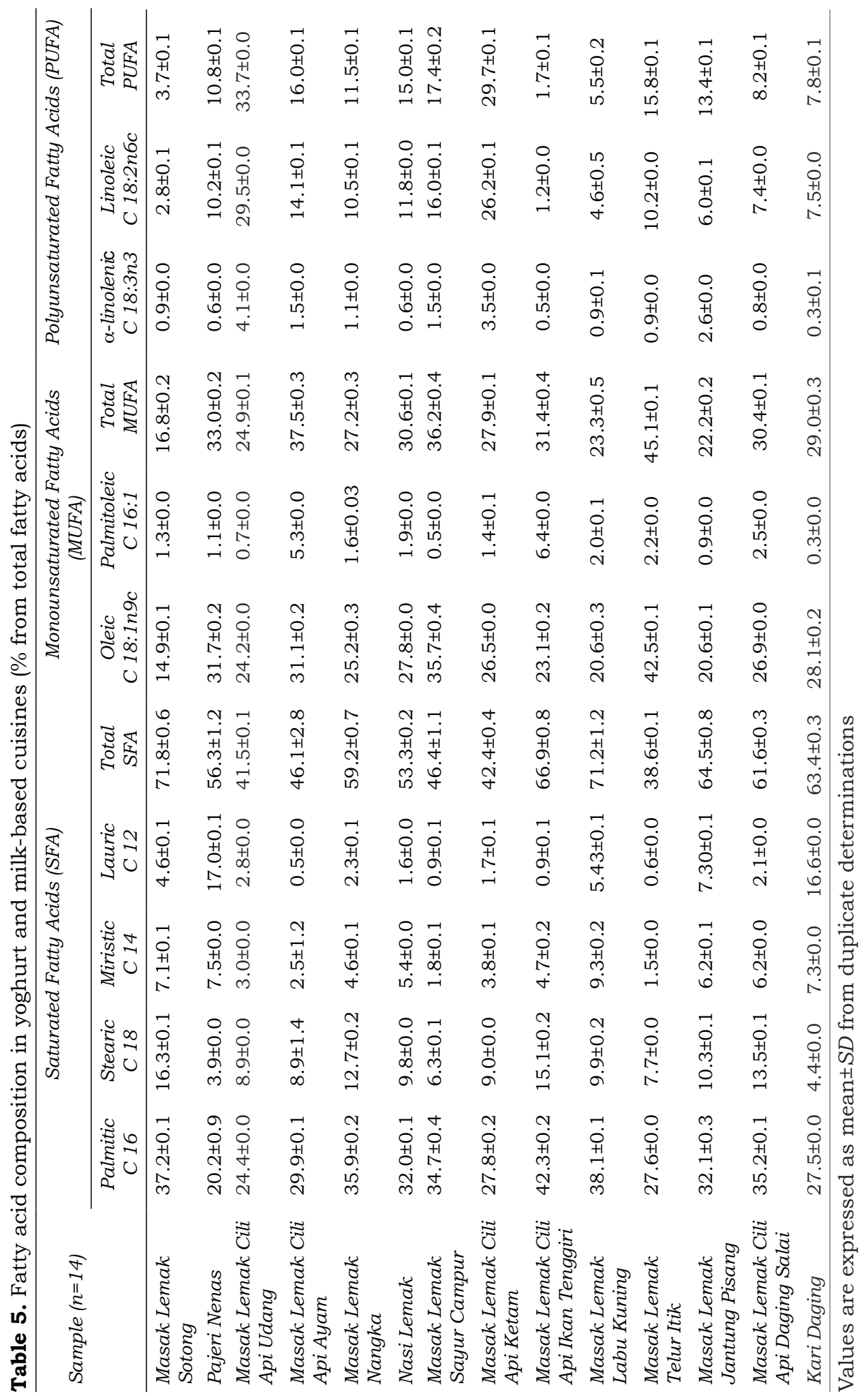


acid was the second highest amount of monounsaturated fatty acids in the analysed cuisines. The highest amount of palmitoleic acid (6.4\%) was found in Masak Lemak Cili Api Ikan Tenggiri. For polyunsaturated fatty acids, Masak Lemak Udang Cili Api showed the highest amount of $\alpha$-linolenic acid $(4.11 \%)$ and linoleic acid (29.5\%). Abdullah et al. (2009) showed that total polyunsaturated fatty acids in two types of fresh shrimp were the highest (42\% and $35 \%$, respectively). Trans-fatty acid could only be found in small amounts $(0.19 \%)$ in Nasi Lemak and $0.06 \%$ for both Masak Lemak Telur Itik and Kari Daging.

All these new findings will be added to the database of the Malaysian Food Composition. However, the limitation of this study was that only foods and beverages in the recipe book were analysed. Future research should consider collecting and analysing food samples from across Malaysia.

\section{CONCLUSION}

Based on the nutrient content obtained from each food and beverage in this study, overweight and obesity problems among respondents could be overcome by implementing the recommended modifications made during meal preparations. The food analysis carried out gave reliable results on the determination of nutrient contents in the recipes. Food analysis results showed that out of 48 types of dishes and 12 types of healthy beverages, Sambal Ikan Bilis showed the highest amount of ash, protein, iron and magnesium; while protein, fat, sodium and potassium contents were highest in Ayam Bakar Berempah $(p<0.05)$. Saturated fatty acids were found abundant in Masak Lemak Sotong, Masak Lemak Labu Kuning, and
Masak Lemak Cili Api Ikan Tenggiri, while the lowest saturated fatty acids could be found in Masak Lemak Telur Itik. Monounsaturated fatty acids were found highest in Masak Lemak Telur Itik, while the lowest amount was present in Masak Lemak Sotong. Besides, the highest amount of polyunsaturated fatty acids was shown in Masak Lemak Cili Api Udang, while the lowest was in Masak Lemak Cili Api Ikan Tenggiri. The results of this study will make the recipe book more meaningful as the food analysis found most of the modified recipes showed lower caloric content compared to the original recipes. Reducing calories and fat in foods to an equally liked preference may be a strategy to improve one's dietary intake when preparing these foods. This approach takes the burden off the individuals in making healthier choices.

\section{Acknowledgement}

The authors would like to acknowledge the assistance provided by the committee and residents of Masjid Tanah, Malacca, who contributed significantly to the successful completion of the study. We are also extremely grateful to the staffs from the Nutritional Sciences Programme, Faculty of Health Sciences, Universiti Kebangsaan Malaysia and Institute for Medical Research (IMR) for their assistance in using the food analysis laboratory facilities. This study was funded by the Universiti Kebangsaan Malaysia Arus Perdana (AP 2014-025) research grant.

\section{Author's contributions}

NA, conducted the study and compiled the data, data analysis and interpretation, prepared the draft of the manuscript; WNNWN and WM, assisted in the study and reviewed the manuscript; $\mathrm{HH}$, conceptualised and designed the study, provided advice on data analysis and its interpretation, and reviewed the manuscript; RAT, conceptualised and designed the study, provided advice on data analysis and its interpretation, and reviewed the manuscript.

\section{Conflict of interest}

Authors declare no conflict of interest. 


\section{References}

AOAC (2007). Official Method of Analysis of AOAC International. 18th Edition. Association of Official Analytical, Chemists, Gaithersburgs, MD.

Abdullah Oksuz, Ayse Ozyilmaz, Mevlut Aktas, Gozde Gercek \& Jelena Motte (2009). A comparative study on proximate, mineral and fatty acid compositions of deep seawater rose shrimp and red shrimp. J Anim Vet Adv 8(1):183-189.

America's Test Kitchen \& Global Crosby G (2012). The science of good cooking. Massachusetts: America's Test Kitchen, Brookline.

Amonrat T, Soottawat B \& Wonnop V (2006). Chemical composition and thermal property of cuttlefish (Sepia pharanhms) muscle. J Food Compos Anal 19: 127-133.

Atwater WO \& Bryant AP (1900). The availability and fuel value of foods materials. Report of the Storrs Agricultural Experiment Station, Storrs 1899:3-110, Storrs, CT: University of Connecticut.

Dora R, Haron H, Shahar S, Phang CC, Fauzi MFM $\&$ Noh MFN (2018). Macronutrients and sugar content in foods and beverages from three selected zones in Peninsular Malaysia. Sains Malays 47(7):1557-1562.

Edem CA, Dounmu MI, Bassey FI, Wilson C \& Umoren P (2009). A comparative assessment of the proximate composition, ascorbic acid and heavy metal content of two species of garden egg (solanum gilo and solanum aubergine). Pak $J$ Nutr 8(5):582-84.

Ehigiator FAR \& Nwangwu IM (2011). Comparative studies of the proximate composition of three body parts of two freshwater prawns' species from Ovia River, Edo State, Nigeria. Aust $J$ Basic \& Appl Sci 5(12):2899-2903.

Fukuda T, Hamaguchi M \& Kojima T (2016). The impact of nonalcoholic fatty liver disease on incident type 2 diabetes mellitus in nonoverweight individuals. Liver Int 36:275-283.

Gharibzahedi SMT \& Jafari SM (2017). The importance of minerals in human nutrition: Bioavailability, food fortification, processing effects and nanoencapsulation. Trends Food Sci Technol 62:119-132.

Hegde SV, Adhikari PMN \& D'Souza V (2013). Effect of daily supplementation of fruits on oxidative stress indices and glycaemic status in type 2 diabetes mellitus. Complement Ther Clin Pract 19(2):97-100.
IZiNCG (2004). Assessment of the risk of zinc deficiency in populations and options for its control. International Zinc Nutrition Consultative Group Technical Document \#1. Food Nutr Bull 25(1):94-203.

IPH (2015). National Health and Morbidity Survey 2015 (NHMS 2015) Vol. II: Non-Communicable Diseases, Risk Factors \& Other Health Problems. Institute for Public Health, Ministry of Health Malaysia, Malaysia. ISBN 978-983-2387-23-7.

IPH (2019). National Health and Morbidity Survey 2019 (NHMS 2019). Institute for Public Health, Ministry of Health Malaysia, Malaysia.

IUPAC (1987). Standard methods for the analysis of oils, fats and derivatives (7th ed.). International Union of Pure \& Applied Chemistry. Blackwell Scientific Publications, Boston [Method 2.301].

Jordan GS, Maggie S, Evaline A \& Myles SF (2010). Primary care providers' knowledge, practices, and perceived barriers to the treatment and prevention of childhood obesity. $J$ Obes 18:1341-1347.

Malaysian Food Composition Database (2019). History of Food Composition Database. From: http://myfcd.moh.gov.my/index.php/aboutus / history-of-food-composition-database. [Retrieved August 29 2019]

Manal ST (2009). Proximate composition and fatty acid profiles in most common available fish species in Saudi Market. Asian J Clin Nutr $1(1): 50-57$.

McCance \& Widdowson's The Composition of Foods Seventh Summary Edition (2014). Royal Society of Chemistry: Cambridge.

Merrill AL \& Watt BK (1973). Energy Value of Foods-Basis and Derivation. US Department of Agriculture, Agriculture Handbook 74:105.

Nandita SD (2013). Development of a modified low fat recipe from an original recipe for obese. Int J Food Nutr Sci 2(2):95-97.

Nielsen SS (2017). Introduction to Food Analysis. In: Nielsen S. (eds) Food Analysis. Food Science Text Series. Springer, Cham.

NCCFN (2010) Malaysian Dietary Guidelines. National Coordinating Committee on Food and Nutrition, Ministry of Health Malaysia, Putrajaya.

Pallab D \& Amartya D (2012). Development of standardization of Gita Pachak Haritaki-a polyherbal formulation. Int $J$ Res Pharm Biomed Sci 3(2):748-756. 
Sankar TV, Anandan R, Suseela M, Asha KK, Lakshmanan PT, Jones V, Aneesh PA \& Mohanty BP (2013). Chemical composition and nutritional value of Anchovy (Stolephorus commersonii) caught from Kerala coast, India. Eur J Exp Biol 3(1):85-89.

Slavin JL \& Llyod B (2012). Health benefits of fruits and vegetables. J Adv Nutr 3:506-516.

Varadharajan D \& Soundarapandian P (2014). Proximate composition and mineral contents of freshwater crab Spiralothelphusa hydrodroma (Herbst, 1794) from Parangipettai, South East Coast of India. J Aquac Res Dev 5(2):1-6.
Vassilia JS, Irini FS \& Sofia M (2011). Lipid, fatty acid and carotenoid content of edible egg yolks from avian species: a comparative study. $J$ Food Chem 124:971-977.

WHO (2020). In: Obesity and overweight. Fact sheet on March 2020. From: https://www.who.int/ news-room/fact-sheets/detail/obesity-andoverweight [Retrieved March 18 2020]. 